\title{
Research Notes: International Relations Theories, Article 95EC Legal Basis and the Delimitation of Competences Between the EU and the Member States
}

\section{Anatole Abaquesne De Parfouru}

THE QUESTION OF THE DIVISION OF COMPETENCES BETWEEN THE EUROPEAN UNION (EU) and its Member States has been a major point of focus of reform proposals for the EU legal order in recent years. The importance of this issue was stressed in the Nice and Laeken Declarations, in the light of seemingly contradictory claims of 'competence creep' on the one hand, and criticisms of Union inaction in policy fields in which it has very limited competence on the other hand. Clarifying the delimitation of powers was the subject of much attention in the debate preceding the adoption of the 2004 Constitutional Treaty, abandoned as a result of the French and Dutch referenda of $2005 .^{2}$ It contained a number of innovations in this respect, such as the formal abolition of the Pillar structure, the categorization of Union powers, or the use of national parliaments to monitor the application of the principle of subsidiarity. Most of these reforms have been integrated in the Treaty of Lisbon, signed last December, but the future of which is uncertain as a result of its rejection in the Irish referendum of June. ${ }^{3}$

As it now stands, ${ }^{4}$ my research project endeavours to analyse the delimitation of powers between the Union and the Member States through the lens of the Article 95EC

\footnotetext{
${ }^{1}$ Declarations Adopted by the Nice Intergovernmental Conference, para.23 (5) (Declaration on the future of the Union); and Declaration on the Future of the European Union, Annex to the Laeken European Council Presidency Conclusions, SN 300/1/01 REV 1.

${ }^{2}$ Treaty establishing a Constitution for Europe, O.J. 2004 C310/1.

${ }^{3}$ Treaty of Lisbon amending the Treaty on the European Union and the Treaty establishing the European Community (renamed Treaty on the Functioning of the European Union (TFEU)), O.J. 2007 C 306/1. See Articles 2 to 6 TFEU and the Protocol on the Application of the Principles of Subsidiarity and Proportionality.

${ }^{4}$ The research originally undertaken was much broader in scope, examining the division of competences between the EU and its Member States, without the framework of the Article 95EC legal basis. One part was to be devoted to the classification of Union powers and the analysis of the legal bases, while the other part would have examined the judicial and political framework enforcing the delimitation of powers (G. de Búrca \& B. de Witte, 'The Delimitation of Powers Between the EU and its Member States', in Arnull \& Wincott (eds.), Accountability and Legitimacy in the European Union (Oxford: OUP, 2002), pp.205-6), as well as the principles of subsidiarity and proportionality.
}

This article has been written by a student participant of the 'Legal Research Methodologies in European Union and International Law' workshop series as detailed in the three Research Notes articles by Hervey et al. (2007, 2008a \& 2008b). The article introduces the student's PhD project and details some of the methodological research issues which the AHRC funded workshops have helped the student to address.

Abaquesne De Parfouru, A. (2008). 'Research Notes: International Relations Theories, Article 95EC Legal Basis and the Delimitation of Competencies Between the EU and the Member States', Journal of Contemporary European Research, Vol. 4, No. 3, pp.248-252. Available: http://www.jcer.net/ojs.index.php/jcer/article/view/137/110. 
legal basis. It focuses on four major aspects.

\section{Article 95EC and other policy fields: Use or abuse of Article 95EC?} Extension of Community powers through Article 95EC?

Article 95EC - Article 114TFEU if and when the Treaty of Lisbon enters into force constitutes a general internal market legal basis. It has been used by the Union legislator to adopt secondary EC legislation that has included both internal market and "non-market" objectives, and arguably even legislation that predominantly concerns "non-market" goals. ${ }^{5}$ Article 95EC provides for the adoption of measures for the approximation of laws, having as their object the establishment and functioning of the internal market. ${ }^{6}$ However, as De Witte notes, "internal market legislation is always also 'about something else'". 7 My research project examines the legislation adopted under Article 95EC in order to determine whether the Union legislator has 'abused' this legal basis in adopting secondary legislation with a primary purpose other than its stated internal market objective. It also examines the role of the Court in sanctioning, or failing to sanction any abuse of this provision by the Community legislator. This brings us to the question raised by the kompetenz-kompetenz debate: "whether the Community possesses [and whether it should possess] the autonomy to define the limits of its own competences". 8

The use of Article 95EC may affect the delimitation of powers between the Union and its Member States in two distinct ways. "Inner limit" situations arise where the EC legislation could arguably have been adopted under another specific legal basis providing for a different legislative procedure, ${ }^{9}$ a different voting method in Council, or a limited form of harmonization. ${ }^{10}$ Article $95 \mathrm{EC}$ refers to the Article $251 \mathrm{EC}$ co-decision procedure (whereby the European Parliament acts as co-legislator and a qualified majority vote (QMV) applies in Council), and so supranationalism is favoured over intergovernmentalism when the EC legislator adopts measures under this legal basis. It should be noted that the occurrence of this type of situation is likely to decrease if and when the Treaty of Lisbon enters into force, as the latter Treaty provides that QMV and the co-decision procedure - to become the 'ordinary legislative procedure' (OLP) - will be generalized." "Outer limit" situations arise where, had the Community measure not been adopted under Article 95EC, it would not have been adopted at all, as a result of express exclusions of harmonization in the Treaty: the measure is either validly based on Article 95EC or it is ultra vires. ${ }^{12}$

International relations (IR) theories provide useful tools when analysing the relationship between Article 95EC and other policy fields. Neo-functionalism constitutes a

\footnotetext{
${ }^{5}$ B. de Witte, 'Non-Market Values in Internal Market Legislation', in N. Nic Shuibhne, Regulating the Internal Market (Cheltenham: Edward Elgar, 2006); S. Weatherill, 'Supply of and Demand for Internal Market Regulations: Strategies, Preferences and Interpretation', in N. Nic Shuibhne, Regulating the Internal Market (Cheltenham: Edward Elgar, 2006).

${ }^{6}$ Article 95(1)EC.

${ }^{7}$ B. de Witte, 'Non-Market Values in Internal Market Legislation', above note 5, p.76.

${ }^{8}$ P. Craig \& G. de Bùrca, EU Law: Text, Cases and Materials (Oxford: OUP, 2003), p.284. See also Weiler, The Constitution of Europe (Cambridge: CUP, 2000), p.311.

${ }^{9}$ The 'horizontal' division of powers thus affects the 'vertical' division of competences.

${ }^{10}$ A. Knook, 'Guns and Tobacco. The Effect of Interstate Trade Case Law on the Vertical Division of Powers', (2004) 11 MJ 347, p.357.

${ }^{11}$ New Article 16(3)TEU as inserted by the Lisbon Treaty, and Article 294TFEU.

${ }^{12}$ A. Knook, 'Guns and Tobacco', above note 10, p.357. See also: K. Bradley, 'The European Court and the legal basis of Community legislation', (1988) 13 ELRev 379; S. Crosby, 'The New Tobacco Control Directive: An Illiberal and Illegal Disdain for the Law' (2002) 27 ELRev 177; T. Hervey, 'Community and national competence in health after Tobacco Advertising' (2001) 38 CMLRev 1421; T. Hervey, 'Up in Smoke? Community (Anti) Tobacco Law and Policy' (2001) 26 ELRev 101; T. Hervey, 'The Legal Basis of European Community Public Health Policy', in McKee, Mossialos \& Beaten (eds.), The Impact of EU Law on Health Care Systems (Brussels: P.I.E.- Peter Lang, 2002); D. Wyatt, 'Community Competence to Regulate the Internal Market', University of Oxford Faculty of Law Legal Studies Research Paper Series, Working Paper N9/2007, July 2007.
} 
particularly interesting perspective, with its concept of 'functional spillover', whereby "if there [is] integration in one sphere it [will ...] create pressure for integration in another field". ${ }^{13}$ Economics is another discipline that constitutes a useful lens, when analysing the case-law on the boundaries of the Article 95EC legal basis, as is exemplified by Tridimas and Tridimas in their "economic efficiency" analysis of the first Tobacco Advertising ruling. ${ }^{14}$

Another IR theory, multi-level governance - whereby "decision-making competences 'are shared by actors at different levels rather than monopolized by state executives'" ,${ }^{15}$ comes into play when analysing the principles of conferral, proportionality and subsidiarity, and, to a certain extent, when considering the role envisaged by both the Constitutional and Lisbon Treaties for national parliaments in monitoring the application of the principle of subsidiarity. ${ }^{16}$

\section{Types of harmonization adopted under Article 95EC}

A second part of this research project examines the types of harmonization adopted under Article 95EC: 'total'/ 'full' harmonization, minimum harmonization, 'new approach to technical harmonization', etc. Articles 95(4)-(9)EC provide scope for 'more stringent national measures', ${ }^{17}$ and constitute an example of sharing of decisionmaking power between the supranational and the national levels, and accordingly an example of multi-level governance. Similarly, the 'new approach to technical harmonization' can be analysed from either a multi-level governance or a 'new governance' approach. This section also examines types of pre-emption applied by the Court and the Community legislator, which are best analysed from a federalist perspective. ${ }^{18}$ Thus, once again IR theories provide an indispensable tool for the analysis of the delimitation of powers between the Union and its Member States.

\footnotetext{
${ }^{13}$ P. Craig, 'The Nature of the Community: Integration, Democracy, and Legitimacy', in P. Craig \& G. de Búrca (eds.), The Evolution of EU Law (Oxford: OUP, 1999), p.3. See also E. Haas, The Uniting of Europe (London: Stevens \& Sons, 1958) and A. Burley \& W. Mattli, 'Europe Before the Court: A Political Theory of Legal Integration' (1993) 47 International Organization 41, referred to by G. de Búrca, 'Rethinking Law in Neofunctionalist Theory' (2005) 12 Journal of European Public Policy 310, pp.315-6; and S. George, Politics and Policy in the European Union (Oxford: OUP, 1996), pp.37-8;

${ }^{14} \mathrm{G}$. Tridimas \& T. Tridimas 'The European Court of Justice and the Annulment of the Tobacco Advertising Directive: Friend of National Sovereignty or Foe of Public Health?' (2002) European Journal of Law and Economics 171, pp.175-7.

${ }^{15} \mathrm{P}$. Craig, 'The Nature of the Community: Integration, Democracy, and Legitimacy', above note 13, p.17, quoting G. Marks, L. Hooghe \& K. Blank, 'European Integration from the 1980s: State-Centric v. Multiple Level Governance', (1996) 34 JCMS 341, p.346.

${ }^{16}$ See The Protocol on the Application of the Principles of Proportionality and Subsidiarity, annexed to the Lisbon Treaty, in particular Article 7(3), added to the provisions of the Protocol from the Constitutional Treaty. See in particular: G. Barrett, "The King is Dead, Long Live the King": The Recasting by the Treaty of Lisbon of the Provisions of the Constitutional Treaty Concerning National Parliaments' (2008) 33 ELRev 66.

${ }^{17}$ Recent cases, like the first Tobacco Advertising ruling, suggest that Article 95EC legislation may not allow 'stricter national rules' outside the framework of the Articles 95(4)-(9)EC derogation procedure, in other terms that Article 95EC measures may not include 'minimum harmonization clauses'. In effect, the 2000 Tobacco Advertising case seems to indicate that, for a measure to be validly adopted under the Article 95EC legal basis, it should include a 'free movement clause'. See S. Weatherill, 'Supply of and Demand for Internal Market Regulations: Strategies, Preferences and Interpretation', above note 5, p.47. See also M. Dougan, 'Minimum Harmonization and the Internal Market' (2000) 37 CMLRev 853, pp.878-84.

${ }^{18}$ See in particular: R. Schütze, 'Supremacy without Pre-emption? The very slowly emergent doctrine of Community pre-emption' (2006) 43 CMLRev 1023. See also: E. Cross, 'Pre-emption of Member State Law in the European Economic Community: a framework for analysis' (1992) 29 CMLRev 447; M. Walbroeck, 'The Emergent Doctrine of Community Pre-emption - Consent and Re-delegation', in Sandalow \& Stein, Courts and Free Markets: Perspectives from the US and Europe, Volume 2 (Oxford: Clarendon Press, 1982); S. Weatherill, 'Beyond Pre-emption? Shared Competence and Constitutional Change in the European Community', in O'Keeffe \& Twomey (eds.), Legal Issues of the Maastricht Treaty (Wiley Chancery Law, 1994); S. Weatherill, 'Pre-emption, Harmonisation and the Distribution of
} 


\section{Articles 95(4)-(9)EC derogations}

Another aspect of the research undertaken focuses on the derogation procedure in Articles 95(4)-(9)EC, referred to above, whereby Member States can "maintain" or "introduce" national provisions notwithstanding the existence of an Article 95(1)EC harmonization measure. We have noted that this constitutes an instance of multi-level governance, whereby "decision-making competences are 'shared by actors at different levels'", the supranational and the national levels. ${ }^{19}$ The proportionality assessment undertaken by the Commission under Article 95(6) provides a basis for deciding whether the national measures should be authorized, and thus whether the Member State is entitled to share decision-making power with the supranational level. ${ }^{20}$ However, the strict line adopted by both the Commission and the Court in relation to such Articles 95(4) and (5) derogation requests testifies of the unwillingness of Union institutions to surrender their supranational decision-making powers. ${ }^{21}$ This is further demonstrated by the Commission's application of Article 95(5) criteria to Article 95(4) situations - where the Member State wishes to "maintain" existing national provisions rather than "introduce" new ones. ${ }^{22}$

\section{The relationship between the Community's 'deregulatory' competence and its 'regulatory' power under Article 95EC}

A final aspect of this research project will consider the relationship between the 'deregulatory' provisions of the EC Treaty and the 'regulatory' powers under Article 95EC (and 94EC). For example, Knook notes the "cross-pollination effect" between Articles 28EC and 95EC, in other words, "when the ECJ holds a Member State measure prima facie to fall within the scope of Article 28, but justified under Article 30, it allocates the competence to regulate on the subject matter to the Community level inter alia under Article $95^{\prime \prime 2} .^{23}$ Once again, this can be analysed as an instance of neofunctionalism, with its logic of 'functional spillover'. ${ }^{24}$ This brings us back to the kompetenz-kompetenz debate considered above, that is the issue of "whether the Community [the Court, but also the Community legislator when 'abusing' the Article 95EC legal basis] possesses the autonomy to define the limits of its own competences", and, most importantly, whether it should possess such an autonomy. ${ }^{25}$

Lawyers are snobbish by nature. Or are they really? It is generally assumed that academics - and not only lawyers, but also political scientists, sociologists, economists, historians, etc - are straight-jacketed by their own disciplines, and by the concepts and methodologies that their discipline entails. The paper by Hunt and Shaw, entitled 'Fairy Tale of Luxembourg? Reflections on Law and Legal Scholarship in European Integration', ${ }^{26}$ tends to demonstrate the contrary, by highlighting the recent evolution of EU legal scholarship away from the traditional positivist approach. ${ }^{27}$ Not only does

Competence to Regulate the Internal Market', in C. Barnard \& J. Scott, The Law of the Single European Market: Unpacking the Premises (Oxford: Hart, 2002).

${ }^{19}$ P. Craig, 'The Nature of the Community: Integration, Democracy, and Legitimacy', above note 13, p.17, quoting G. Marks, L. Hooghe \& K. Blank, 'European Integration from the 1980s: State-Centric v. Multiple Level Governance', (1996) 34 JCMS 341, p.346.

${ }^{20}$ R. Verheyen, 'Article 95 EC Treaty in Practice: The European Commission Decisions on Creosote, Sulphite, Nitrates and Nitrites' (2000) 9 RECIEL 71, p.73.

${ }^{21}$ Ibid., pp.74-5.

22 lbid., pp.72 and 74.

${ }^{23}$ A. Knook, 'Guns and Tobacco', above note 10, pp.374-5. This research project will consider inter alia to what extent the Community legislator has used this opportunity provided by the Court.

${ }^{24}$ P. Craig, 'The Nature of the Community: Integration, Democracy, and Legitimacy', above note 13, p.3. ${ }^{25}$ P. Craig \& G. de Bùrca, EU Law: Text, Cases and Materials, above note 8, p.284.

${ }^{26} \mathrm{~J}$. Hunt and J. Shaw, 'Fairy Tale of Luxembourg? Reflections on Law and Legal Scholarship in European Integration', in A. Warleigh-Lack (ed.), Reflections on European Integration: 50 Years of the Treaty of Rome (forthcoming).

27 lbid., p.8. 
EU legal scholarship take its "methodological approaches and theoretical assumptions [...] from other sub-disciplines in law", international law, public and private law, ${ }^{28}$ but the sui generis nature of Union law has also led legal academics to consider the EU's "interactions with national level constitutional orders", issues of morality, "effectiveness and legitimacy", political science/international relations theories, such as supranationalism, intergovernmentalism, neofunctionalism and multi-level governance, as well as 'new governance' theories. ${ }^{29}$ Moreover, the cross-policy nature of EU law forces legal academics into the realms of individual policy fields - such as social policy, public health, environmental protection, or foreign policy (CFSP) -, as well as economics and social science. ${ }^{30}$ Going in the sense of this evolution of legal scholarship, the purpose of the workshop on Legal Research Methodologies in European Union and International Law, held at the University of Sheffield on $27-28^{\text {th }}$ June, was to introduce or re-introduce various cross-disciplinary theoretical and methodological approaches to lawyers, thereby broadening their perspective. ${ }^{31}$ Theories allow us to rationalize and challenge our assumptions. In particular, examination of political science theories which focus on political and societal actors, on "causal mechanisms", on the "dynamics of political and social change", on the "linkages and interdependencies between different policy fields and between different actors", and on the locus of "political loyalties and expectations" - 32 enable legal scholars to take a necessary step back to analyse decision-making in the EU. In a recent article, De Búrca reaches the conclusion that, in the same way that law provides an essential tool to the political scientist, "law is a complex social phenomenon, and an understanding of its place in the process of European integration requires the kind of explanatory theory which political scientists [...] have striven to develop and which legal scholarship has rarely seriously addressed" ${ }^{34}$ IR theories therefore constitute an indispensable analytical framework to question the direction taken by the EU.

\section{Bibliography}

Hervey, T., Cryer, R. \& Sokhi-Bulley, B. (2007). 'Legal Research Methodologies in European Union and International Law: Research Notes (Part 1)', Journal of Contemporary European Research, 3 (2), pp.161-165.

Hervey, T., Cryer, R. \& Sokhi-Bulley, B. (2008a). 'Legal Research Methodologies in European Union and International Law: Research Notes (Part 2)', Journal of Contemporary European Research, 4 (1), pp.48-51

Hervey, T., Cryer, R. \& Sokhi-Bulley, B. (2008b). 'Legal Research Methodologies in European Union and International Law: Research Notes (Part 3)', Journal of Contemporary European Research, 4 (3), pp.200-204.

\footnotetext{
${ }^{28}$ Ibid., p.6.

${ }^{29}$ lbid., pp.5, 7 and 8 respectively.

${ }^{30}$ Ibid., pp.5 and 7 respectively.

${ }^{31}$ AHRC Collaborative Doctoral Training Project ID 06/ 160/ S 1 Oct 2006 - 30 Sept 2008. These workshops were organized by Tamara Hervey, Robert Cryer and Bal Sokhi-Bulley,

${ }^{32}$ G. de Búrca, 'Rethinking Law in Neofunctionalist Theory', above note 13, pp.314, 317 and 316 respectively.

33 lbid., pp.319-21.

34 Ibid., p.323.
} 